\title{
Effect of Pre-harvest Fruit Bagging on Physical and Physiological Properties of Pomegranate (Punica granatum, L.) cv. Phule Bhagwa Super
}

\author{
A. S. Gethe, S. A. Hiray, C. V. Pujari* and R. V. Patil \\ College of Agriculture (MPKV), Dhule, Maharashtra (India) \\ *Corresponding author
}

Keywords

Pomegranate, Bagging materials, Physical properties, PLW, Shelf life

Article Info

Accepted:

12 January 2021

Available Online:

10 February 2021
An investigation was undertaken to study the effect of pre-harvest fruit bagging on physical and physiological properties of pomegranate (Punica granatum L.) cv. Phule Bhagwa super during 2019-2020 in Randomized Block Design. Pomegranate fruits were bagged 30 days after fruit set with different types of bags viz.Butter paper bag $\left(\mathrm{T}_{1}\right)$, Brown paper bag $\left(\mathrm{T}_{2}\right)$, Parchment bag $\left(\mathrm{T}_{3}\right)$, English newspaper bag $\left(\mathrm{T}_{4}\right)$ (60 gsm), Marathi newspaper bag $\left(\mathrm{T}_{5}\right)(35 \mathrm{gsm})$ and Control $\left(\mathrm{T}_{6}\right)$ (without bagging). Significant influence of bagging treatments was observed on the physical and physiological characters of the pomegranate fruit. Result showed that pomegranate fruit bagged with Parchment bag $\left(\mathrm{T}_{3}\right)$ recorded maximum fruit length $(6.61 \mathrm{~cm})$, fruit diameter $(6.34 \mathrm{~cm})$, fruit weight(316.44 g), marketable yield (25.68 kgplant ${ }^{-1}$ and 19.00 tonha $\left.^{-1}\right)$ and aril percentage (72.89\%). This treatment also recorded minimum PLW $(5.76 \%, 12.23 \%$ and $18.03 \%$ at $3^{\text {rd }}, 6^{\text {th }}, 9^{\text {th }}$ days after harvest, respectively) and maximum shelf life (24.71 days). Bagged fruits were totally free from cracking and sunburn injury.

\section{Introduction}

Pomegranate (Punica granatum, L.) being hardy in nature and versatile in adaptability to different soil and climatic conditions and high yield potential, its cultivation is increasing Maharashtra. In India, pomegranate is grown on an area of 233.93 thousand hectare with the production of 2844.52 thousand million tons. Maharashtra has the highest area under pomegranate in India which is grown on 147.91 thousand hectare with the production of 1789.46 thousand million tons (Saxena, 2018). Not only yield, but the quality of fruit is equally important for domestic as well as export market. Fruit bagging appears to be eco-friendly and efficient toolto enhance the quality of fruit. There is increasing adoption of the practice of fruit bagging in pomegranate. However, there was felt need the asses the proficiency of different types of bags used in pomegranate. With this thought the present experiment was undertaken.

\section{Materials and Methods}

The field experiment was conducted on five years old orchard of the pomegranate cv. Phule Bhagwa Super at Pomegranate Research and Technology Transfer Centre 
(PR\&TTC), Lakhmapur, Tal. Satana, Dist. Nashik during the year 2019-20. The experiment was conducted on Hast bahar. The experiment was set in Randomized Block Design and each treatment was replicated four times. The treatments consisted of Butter paper bag $\left(T_{1}\right)$, - Brown paper bag $\left(T_{2}\right)$, Parchment bag $\left(\mathrm{T}_{3}\right)$, English newspaper bag $\left(\mathrm{T}_{4}\right)$ (60 gsm), Marathi newspaper bag $\left(\mathrm{T}_{5}\right)$ (35 gsm) and Control (T6) (without bagging).Perforations were made on all bags at the bottom of bag $(4 \mathrm{~mm})$ for ventilation for proper development of fruits. Bagging was done 30 days after fruit set. Five fruits were randomly selected per treatment per replication for recording different observations as described below.

\section{Physical parameters}

Length and diameter of fruit were measured with the help of Verniercaliper and was expressed in centimeters $(\mathrm{cm})$, whereas weight of fruit was recorded by using electronic weighing balance and expressed in grams $(\mathrm{g})$.

\section{Aril percentage}

Fruits were carefully cut opened and arils were separated from pericarp/membrane fractions and total aril weight per fruit was obtained. The aril percentage is calculated by using following formula (Wetzstein, et al., 2011).

$$
\text { Aril percentage }(\%)=\frac{\text { Weight of aril }}{\text { Weight of fruit }} \times 100
$$

\section{Physiological parameters}

\section{Physiological loss in weight (PLW) (\%)}

The weight of fruit was recorded at four days interval up to end of shelf life. PLW was calculated by using following formula (Shankar, et al., 2009) and it was expressed in per cent.

$$
\operatorname{PLW}(\%)=\frac{\text { Initial weight fruit }(\mathrm{g})-\text { Final weight of fruit }(\mathrm{g})}{\text { Initial weight of fruit }(\mathrm{g})} \times 100
$$

\section{Shelf life (days)}

The shelf life of fruits was determined by recording the number of days the fruits remained in edible condition during storage. When the spoilage of fruits exceeded 50 per cent, it was considered as the end of storage life of fruit. Shelf life was expressed in terms of days.

\section{Cracked fruit percentage}

The total numbers of cracked and uncracked fruits per plant were counted and fruit cracking was calculated on percent basis (Singh et al.,2014).

$$
\text { Fruit cracking }(\%)=\frac{\text { No of cracked fruits per plant }}{\text { Total no of fruits per plant }} \times 100
$$

\section{Sunburn fruit percentage}

The total numbers of sun burnt and normal fruits per plant were counted and sun burnt fruit percentage was calculated on percent basis (Abdel et al., 2017).

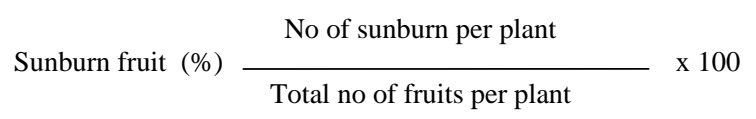

\section{Results and Discussion}

\section{Physical parameters}

\section{Fruit length and fruit diameter $(\mathrm{cm})$}

Pre-harvest bagging with different types of bag did not influence fruit length and fruit diameter as revealed from the Table 1.However, the maximum fruit length (6.51 $\mathrm{cm})$ and fruit diameter $(6.34 \mathrm{~cm})$ was 
recorded in Parchment bag $\left(\mathrm{T}_{3}\right)$. The lowest fruit length $(5.96 \mathrm{~cm})$ and fruit diameter $(5.72$ $\mathrm{cm})$ was registered in control $\left(\mathrm{T}_{6}\right)$.

Similar results were obtained by Muchui et al., (2010) in banana who didn't observe influence of polyethylene bunch covers on bunch weight, finger diameter (grade) and finger length. However, Hussien et al., (1994) observed significant increase in fruit size and weight in pomegranate due to bagging. Islam et al., (2017 b) also observed maximum fruit length (97.93 and $103.5 \mathrm{~mm}$ ) in mango fruits bagged at 35 days after fruit set with white paper and brown paper bag.

\section{Fruit weight (g)}

Irrespective of the bagging material, there was increase fruit weight (Table1 and figure 1). Significantly, the highest fruit weight was observed in treatment Parchment bag $\left(\mathrm{T}_{3}\right)$ which recorded $316.44 \mathrm{~g}$ fruit weightThe next best treatments were Butter paper bag $\left(\mathrm{T}_{1}\right)$ and English news paper bag $\left(\mathrm{T}_{4}\right)$ which recorded $307.47 \mathrm{~g}$ and $305.42 \mathrm{~g}$ fruit weight. respectively. The results are in conformity with the findings of Abd El-Rhman (2010) and Samra and Shalan (2013) who reported higher weight in pomegranate bagging treatments. Salama et al., (2018) also reported highest values for fruit weight of pomegranate trees treated with $780 \mathrm{~g}$ potassium sulphate tree $^{-1}$ and fruit bagged with butter paper bag as compared to unbagged pomegranate fruits cv. Wonderful. Ehteshami et al., (2015) also reported increased size and weight of fruits in pomegranate due to single layer white paper bag. Islam et al., (2017a) observed maximum fruit weight of $329.2 \mathrm{~g}$ in mango bagged 35 days after fruit set with brown paper bags. Debnath and Mithra (2008) in litchi reported that Brown Paper and Newspaper bags showed an increase fruit weight than control and further observed that fruit weight was highest in Newspaper bag $(23.20 \mathrm{~g})$ as compared to control (22.51 g).Increased relative humidity and reduced fruit water loss would have increased fruit weight in bagging treatments.

\section{Marketable Yield (kg plant ${ }^{-1}$ and tonha ${ }^{-1}$ )}

It is evident from the data presented in Table 2 and graphically in Figure 2 and 3, the treatment Parchment bag $\left(\mathrm{T}_{3}\right)$ recorded the highest yield of $25.68 \mathrm{~kg}$ plant $^{-1}$ and 19.0 ton $\mathrm{ha}^{-1}$,respectively. However, the treatments $\mathrm{T}_{1}$ (Butter paper bag), $\mathrm{T}_{4}$ (English newspaper bag), $\mathrm{T}_{2}$ (Brown paper bag) and $\mathrm{T}_{5}$ (Marathi newspaper bag) were on par with each other. Results are in accordance with Samra and Shalan (2013)who reported increase in fruit yield $(\mathrm{kg} /$ tree)in pomegranate due to different bagging treatment. Hegazi et al., (2014) recorded improvement yield in Manfaloty and Wonderfull cultivars of pomegranate due to bagging and spraying with 50 ppm $\mathrm{GA}_{3}, 2$ or $4 \% \mathrm{CaCl}_{2}$ and $5 \%$ kaolin. Similar results were also obtained by Salama et al., (2018) who reported highest values for yield of pomegranate trees treated with $780 \mathrm{~g}$ potassium sulphate tree ${ }^{-1}$ and fruit bagged with butter paper bag as compared to unbagged pomegranate fruits $\mathrm{cv}$. Wonderful. Increase in yield ( $\mathrm{kg}$ plant $^{-1}$ and $\left.\mathrm{t} \mathrm{ha}^{-1}\right)$ of pomegranate is attributed to increase in the fruit size and fruit weight.

\section{Aril percentage}

As observed from the Table 2 and figure 4, pre-harvest fruit bagging with different types of bag significantly influenced Aril percentage. Maximum aril percentage was observed in the treatment. Parchment bag $\left(\mathrm{T}_{3}\right)$ recording 72.89 aril percentage. The treatments $\mathrm{T}_{1}$ (Butter paper bag) and $\mathrm{T}_{4}$ (English newspaper bag) was on par with the treatment $\mathrm{T}_{3}$ (Parchment bag). These treatments recorded 71.71 and 68.30 per cent aril, respectively. Lowest aril percentage was 
observed in $\mathrm{T}_{6}$ (control)which 58.87 per cent.(Table 03)The increase in aril weight and aril per cent might be due to increased cell size and intercellular spaces coupled with accumulation of water, sugars and other soluble solids in greater amount as a result of translocation of metabolites towards the fruits.

Similar findings were reported by Wasselet al., (2015) who observed significant increase in total arils and red arils weight and percentage in pomegranate due to fruit bagging. Ehteshami et al., (2015) also reported increased in aril weight in pomegranate cv. RababNeiriz due to single layer white paper bag. Salama et al., (2018) also reported highest values for average total arils and red arils weight and percentage in pomegranate trees treated with $780 \mathrm{~g}$ potassium sulphate tree ${ }^{-1}$ and fruit bagged with butter paper bag as compared to unbagged pomegranate fruits.

Table.1 Effect of types of bag on fruit length $(\mathrm{cm})$, fruit diameter $(\mathrm{cm})$ and fruit weight $(\mathrm{g})$, in pomegranate cv. Phule Bhagwa Super at harvest

\begin{tabular}{|c|l|c|c|c|}
\hline Treatment & \multicolumn{1}{|c|}{ Treatment detail } & $\begin{array}{c}\text { Fruit length } \\
\text { (cm) }\end{array}$ & $\begin{array}{c}\text { Fruit } \\
\text { diameter } \\
\mathbf{c m} \text { ) }\end{array}$ & $\begin{array}{c}\text { Fruit } \\
\text { weight (g) }\end{array}$ \\
\hline $\mathbf{T}_{\mathbf{1}}$ & Butter paper bag & 6.46 & 6.28 & 307.47 \\
\hline $\mathbf{T}_{\mathbf{2}}$ & Brown paper bag & 6.35 & 6.15 & 292.25 \\
\hline $\mathbf{T}_{\mathbf{3}}$ & Parchment bag & 6.51 & 6.34 & 316.44 \\
\hline $\mathbf{T}_{\mathbf{4}}$ & English newspaper bag & 6.43 & 6.25 & 305.42 \\
\hline $\mathbf{T}_{\mathbf{5}}$ & Marathi newspaper bag & 6.26 & 5.93 & 266.45 \\
\hline $\mathbf{T}_{\mathbf{6}}$ & Control (without bag) & 5.96 & 5.72 & 260.68 \\
\hline & S. E. \pm & 0.21 & 0.16 & 2.02 \\
\hline & C. D. $0.5 \%$ & $\mathrm{NS}$ & $\mathrm{NS}$ & 6.10 \\
\hline
\end{tabular}

Table.2 Effect of types of bag on Marketable yield and aril percentage of pomegranate cv. PhuleBhagwa Super at harvest

\begin{tabular}{|c|l|c|c|c|}
\hline \multirow{2}{*}{ Treatment } & \multirow{2}{*}{ Treatment details } & \multicolumn{2}{|c|}{ Marketable yield } & Aril percentage \\
\cline { 3 - 4 } & & Kgplant $^{-1}$ & t. ha-1 & $(\%)$ \\
\hline $\mathbf{T}_{\mathbf{1}}$ & Butter paper bag & 24.30 & 17.98 & 71.71 \\
\hline $\mathbf{T}_{\mathbf{2}}$ & Brown paper bag & 23.39 & 17.31 & 67.76 \\
\hline $\mathbf{T}_{\mathbf{3}}$ & Parchment bag & 25.68 & 19.00 & 72.89 \\
\hline $\mathbf{T}_{\mathbf{4}}$ & English newspaper bag & 23.96 & 17.73 & 68.30 \\
\hline $\mathbf{T}_{\mathbf{5}}$ & Marathi newspaper bag & 23.13 & 17.11 & 66.80 \\
\hline $\mathbf{T}_{\mathbf{6}}$ & Control (without bag) & 18.65 & 13.80 & 58.87 \\
\hline & S. E. \pm & 0.92 & 0.68 & 2.10 \\
\hline & C. D. $0.5 \%$ & 2.77 & 2.06 & 6.33 \\
\hline
\end{tabular}


Table.3 Effect of types of bag on physiological loss in weight (\%) (PLW) and Shelf life(days) of pomegranate cv. Phule Bhagwa Super at harvest

\begin{tabular}{|c|c|c|c|c|c|}
\hline \multirow[t]{2}{*}{ Treatment } & \multirow[t]{2}{*}{ Treatment detail } & \multicolumn{3}{|c|}{ Physiological loss in weight (PLW) (\%) } & \multirow{2}{*}{$\begin{array}{c}\text { Shelf life } \\
\text { (Days) }\end{array}$} \\
\hline & & 3 DAS & 6 DAS & 9DAS & \\
\hline $\mathbf{T}_{1}$ & Butter paper bag & $\begin{array}{c}6.18 \\
*(14.39)\end{array}$ & $\begin{array}{c}12.45 \\
(20.66)\end{array}$ & $\begin{array}{c}18.14 \\
(25.20)\end{array}$ & 24.33 \\
\hline $\mathbf{T}_{2}$ & Brown paper bag & $\begin{array}{c}6.41 \\
(14.66)\end{array}$ & $\begin{array}{c}12.71 \\
(20.88)\end{array}$ & $\begin{array}{c}18.58 \\
(25.53)\end{array}$ & 23.12 \\
\hline $\mathbf{T}_{3}$ & Parchment bag & $\begin{array}{c}5.76 \\
(13.88)\end{array}$ & $\begin{array}{c}12.23 \\
(20.46)\end{array}$ & $\begin{array}{c}18.03 \\
(25.12)\end{array}$ & 24.71 \\
\hline $\mathbf{T}_{4}$ & English newspaper bag & $\begin{array}{c}6.33 \\
(14.57)\end{array}$ & $\begin{array}{c}12.68 \\
(20.86)\end{array}$ & $\begin{array}{c}18.27 \\
(25.30)\end{array}$ & 23.29 \\
\hline $\mathbf{T}_{5}$ & Marathi newspaper bag & $\begin{array}{c}6.71 \\
(15.01)\end{array}$ & $\begin{array}{c}13.43 \\
(21.49)\end{array}$ & $\begin{array}{c}19.31 \\
(26.06)\end{array}$ & 22.67 \\
\hline $\mathbf{T}_{6}$ & Control (without bag) & $\begin{array}{c}7.88 \\
(16.30)\end{array}$ & $\begin{array}{c}14.48 \\
(22.36)\end{array}$ & $\begin{array}{c}20.47 \\
(26.90)\end{array}$ & 20.51 \\
\hline & S. E. \pm & 0.1103 & 0.1422 & 0.2118 & 0.4575 \\
\hline & C. D. $0.5 \%$ & 0.3326 & 0.4286 & 0.6386 & 1.3790 \\
\hline
\end{tabular}

* Figures in parenthesis indicate Arc sin transformed value

Table.4 Effect of types of bag on Cracked fruit (\%) and sunburn fruit (\%) of pomegranate cv. Phule Bhagwa Super at harvest

\begin{tabular}{|c|l|c|c|}
\hline Treatment & \multicolumn{1}{|c|}{ Treatment detail } & Cracked fruit \% & Sunburn fruit \% \\
\hline $\mathbf{T}_{\mathbf{1}}$ & Butter paper bag & 0.00 & 0.00 \\
\hline $\mathbf{T}_{\mathbf{2}}$ & Brown paper bag & 0.00 & 0.00 \\
\hline $\mathbf{T}_{\mathbf{3}}$ & Parchment bag & 0.00 & 0.00 \\
\hline $\mathbf{T}_{\mathbf{4}}$ & English newspaper bag & 0.00 & 0.00 \\
\hline $\mathbf{T}_{\mathbf{5}}$ & Marathi newspaper bag & 0.00 & 0.00 \\
\hline $\mathbf{T}_{\mathbf{6}}$ & Control (without bag) & 6.00 & 21.50 \\
\hline & S. E. \pm & - & - \\
\hline & C. D. $0.5 \%$ & - & - \\
\hline
\end{tabular}

Fig.1 Effect of types of bag on fruit Weight (g)

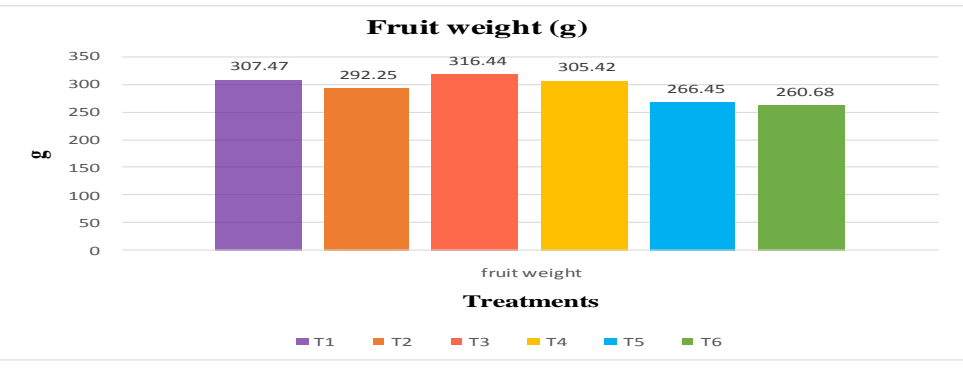


Fig.2 Effect of types of bag on Marketable yield (kg/plant)

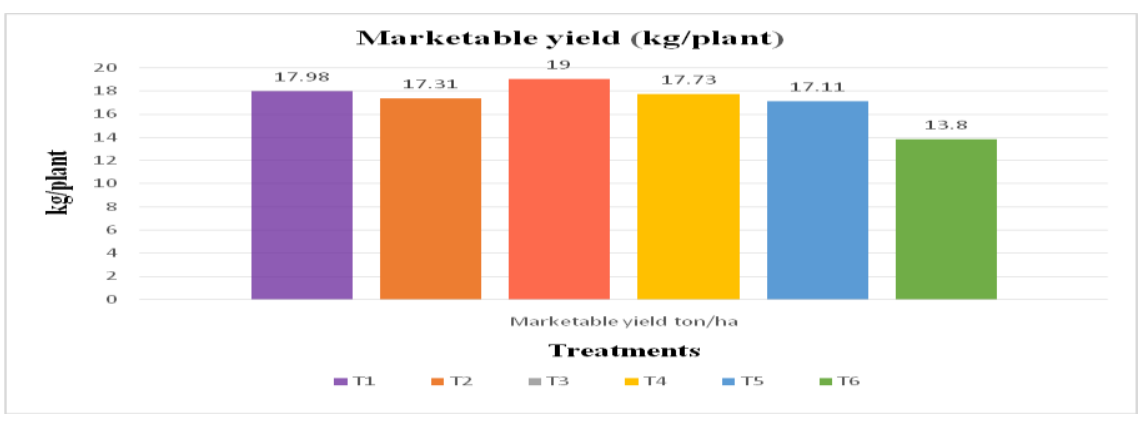

Fig.3 Effect of types of bag on Marketable yield (ton/ha)

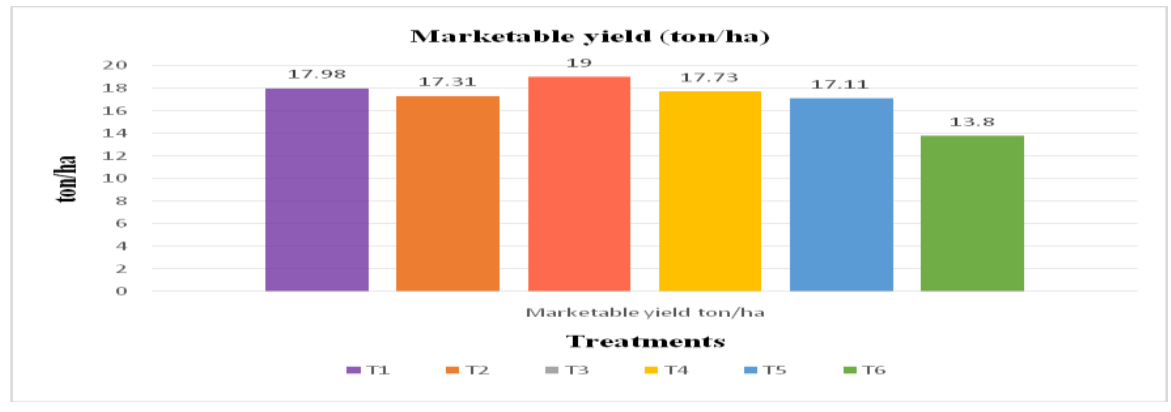

Fig.4 Effect of types of bag on Aril percentage (\%)

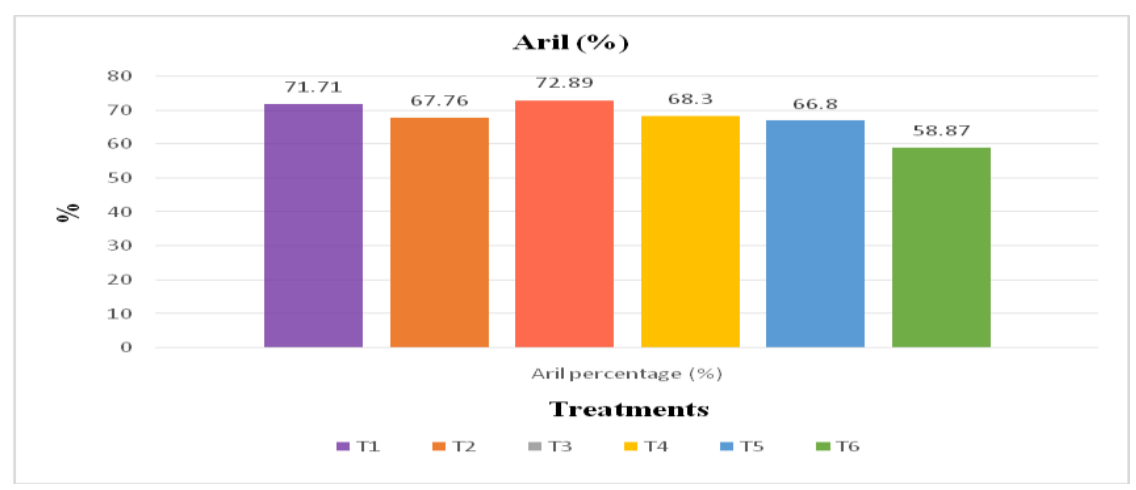

Fig.5 Effect of types of bag on Physiological Loss in Weight (\%)

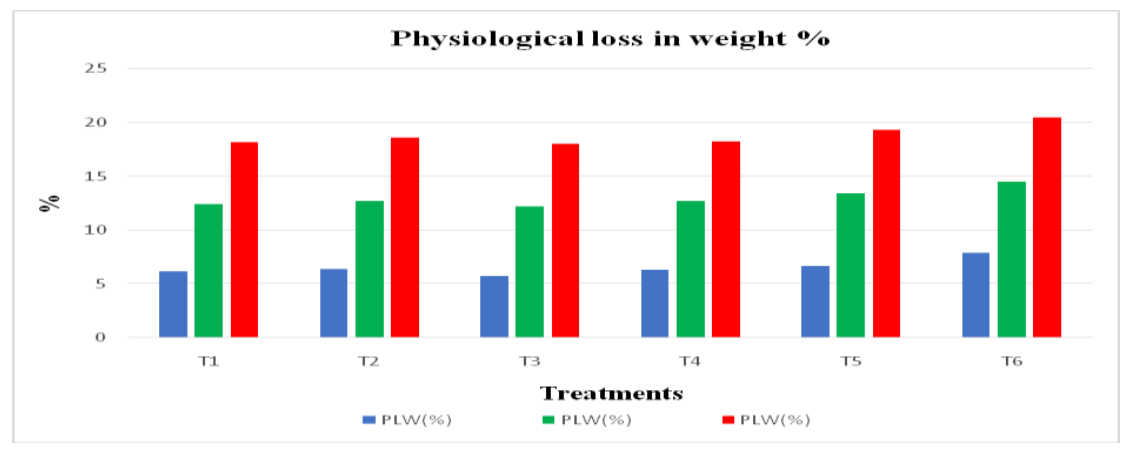


Fig.6 Effect of types of bag on Shelf life (days)

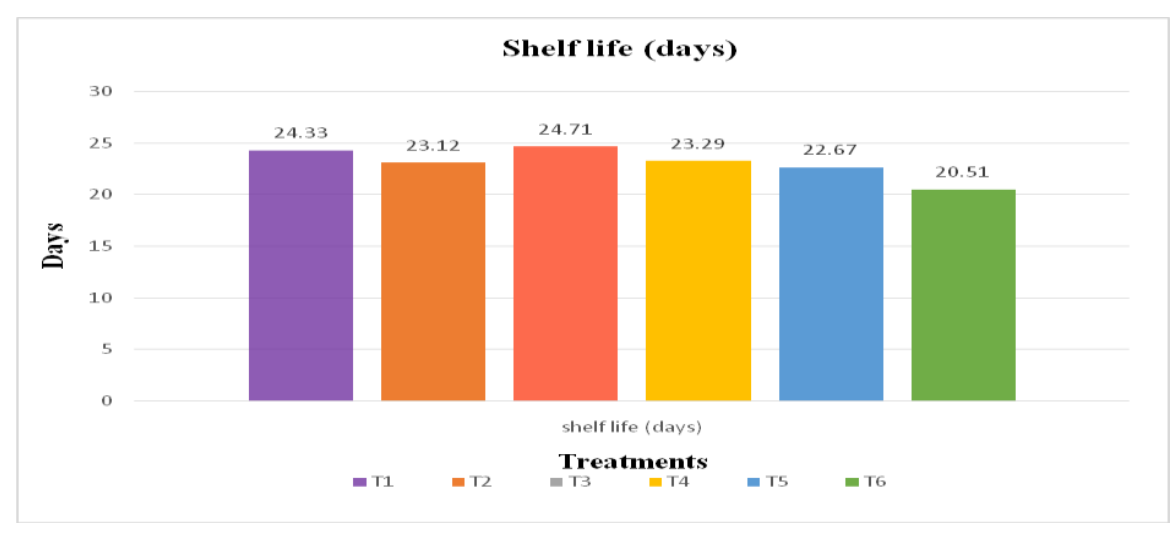

Fig.7 Effect of types of bag on cracked fruit \%

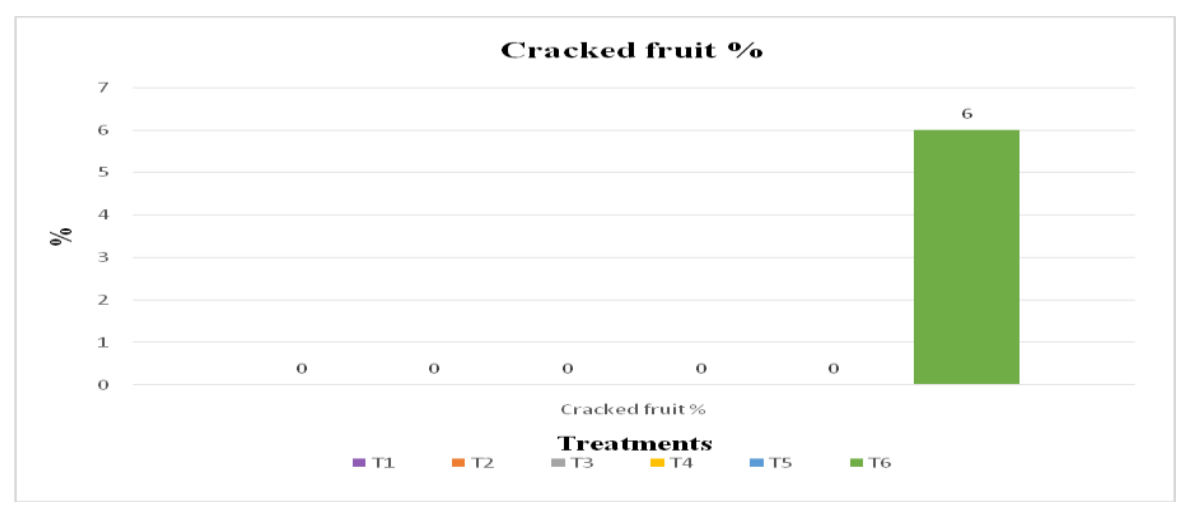

Fig.8 Effect of types of bag on Sunburn fruit \%

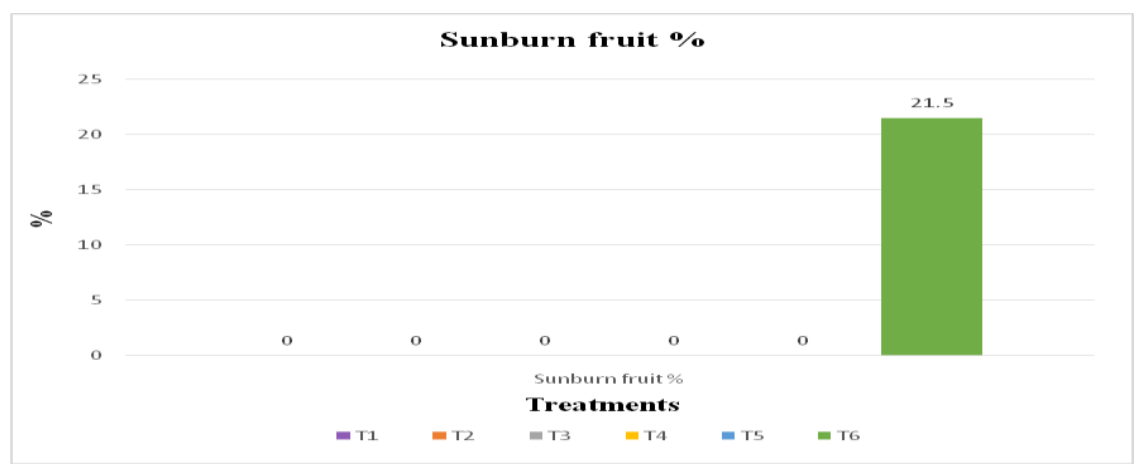

\section{Physiological Parameters}

\section{Physiological loss in weight (\%)}

Physiological Loss in weight indicated significant difference in weight loss among the different bagging treatments and ungagged (control) fruits which increased with the period of storage (Table 3 and figure 5). However, lowest loss in fruit weight was observed in the Parchment bag $\left(\mathrm{T}_{3}\right)$ which was $5.76,12.23$ and 18.03 per cent against 7.88 , 14.48 and 20.47 per cent $\%$ at 3,6 and 9 days after harvest of fruit in the control. Malshe 
and Parulekar (2017) reported lowest physiological loss in weight $(14.67 \%)$ in mango fruits bagged at marble stage and removed bags at 75 days after bagging. In banana, Aryama et al., (2019) noticed higher rate of loss of fruits in control (3.94\%) which was quite higher than the other bagging treatments and the lowest $(1.76 \%)$ rate of weight loss was recorded in bunch covered with non-woven sleeve that was followed by Blue HDPE $(2.17 \%)$ on harvesting day and on $9^{\text {th }}$ day.

Maximum postharvest loss in weight in unbagged (control) fruits might be due to direct exposure of fruits to climate leading to high rate of respiration and transpiration from fruit surface as compared to fruits bagged with different bagging material.

\section{Shelf life (days)}

Bagging significantly improved the shelf life of pomegranate fruits. Maximum shelf life of 24.71 days was registered in Parchment bag $\left(\mathrm{T}_{3}\right)$ treatment. Butter paper bag $\left(\mathrm{T}_{1}\right)$ treatment was at par with the treatment Parchment bag $\left(\mathrm{T}_{3}\right)$ which recorded shelf life of 24.33 days (Table3 and figure 8) (Table 3 and figure 5).Modified microenvironment around the fruit would have delayed the ripening resulting in the improvement in shelf life of pomegranate fruits.

Haldankar et al., (2015)observed maximum shelf life of 17.50 days in mango cv. Alphonso in newspaper bag followed by 16.50 days in brown paper bag.Jakharand Pathak (2016) also observed shelf life up to 12 days with lowest weight loss and highest organoleptic quality in mango cv. Amprapalliin the fruits treated with $2 \%$ $\mathrm{CaCl}_{2}+1 \% \mathrm{~K}_{2} \mathrm{SO}_{4}+$ bagging as against 6 days of untreated fruits (control).Minigire et al., (2017) reported significant effect of bagging on shelf life of mango cv. Ratna and found maximum shelf life of 17.83 days in new paper bag, skirting bag and muslin cloth bag.

\section{Fruit cracking percentage}

No fruit cracking was observed in all the bagging treatments as against 6.0 per cent fruit cracking in control (unbagged fruits) $\left(\mathrm{T}_{6}\right)$.(Table 04 and figure 9). Results are in accordance with Sarkomi et al., (2018) and Grinan et al., (2019) who reported significant reduction in fruit cracking in pomegranate. Rathore and Pal (2016) reported significant reduction in fruit cracking in mango in bagging treatments as compared to unbagged fruit and found blue paper bag most effective in controlling fruit cracking.

Modification of the microclimate around the fruit in pomegranate inside the bag and avoidance of contact with direct strong and hot winds to the skin of fruit would have been effective in reducing the cracking in pomegranate (Yilmaz and Ozguven, 2006).

\section{Sunburn fruit percentage}

No sunburnt fruit were recorded in the all the bagging treatments as against the 21.50 per cent in control (non-bagged fruit) (Table 04 and figure 10).Abou El -Wafa (2014) noticed significant reduction in sun-burn fruits in pomegranate and lowest significant sun burnt fruits (2\%) were recorded in Prgmenbag, whereas it was 25 per cent in control.

Results are in agreement with Sarkomi et al., (2018) and Grinan et al., (2019) who reported significant reduction in peel burn in pomegranate. As reported by Karar et al., (2019), bagged fruits of mango cv. Anwar Rataul had no sunburn injury. As bagging acts as a barrier between sun rays and fruit surface, no sunburn injury was observed in pomegranate. 
In conclusion the results revealed significant effect of bagging treatments on physical parameters, fruit quality and fruit cracking and sun burnt fruits in pomegranate. Among the different bagging materials, Parchment bag appeared to be more promising bagging treatment followed by Butter paper bag and English newspaper bag which had positive effects on physical properties, aril percentage on pomegranate cv. Phule Bhagwa Super. These treatments also exhibited improved shelf life, minimum loss in weight (PLW) and maximum marketable yield.

\section{References}

Abd El-Rhman, I.E. 2010. Physiological studies on cracking phenomena of pomegranates. J. Applied Sci. Res., 6(6), 696-703.

Abdel Gawad-Nehad M.A., EL-Gioushy, S. F. and Baiea, M.H.M. 2017.Impact of different bagging types on preventing sunburn injury and quality improvement of Keitt mango fruits.Middle East Journal of Agriculture Research. 6(2): 484-494.

Abou El-Wafa.M.2014.Effect of Bagging Type on Reducing Pomegranate Fruit Disorders and Quality Improvement. Egypt. J. Hort. 41(2): 263-278.

AryamaDeepti, Shashi Kala and PremPrakas. 2019. Impact of different types of preharvest bunch bagging on postharvest physiological quality of banana cv. Grand Naine. International Journal of Chemical Studies. SP6: 791-793.

Debnath S. and S.K. Mitra.2008.Panicle bagging for maturity regulation quality improvement and fruit borer management in litchi (Litchichinenesis).Acta horticulturae, 773: 201-209.

Ehteshami, S., Sarikhani, H. ,Ershadi, A. and ParianJ. A. 2015. Effect of Bagging on fruit quality and reducing of sunburn in pomegranate cv. RababNeiriz.Iranian Journal of Horticultural Sciences. 45:353360

GrinanI., Donaldo M., Galindo A., Torrecillas A., David P.L., Moriana A., González J.C., Carbonell-Barrachinag A.A. and
Hernándeza F. 2019.Effect of preharvest fruit bagging on fruitquality characteristics and incidence of fruitphysiopathies in fully irrigated and waterstressed pomegranate trees. Journal of the Science of Food and Agriculture 99: 1425-1433.

Haldankar, P. M., Y. R. Parulekar, A.Kireeti, M. S. Kad, S. M. Shinde and K. E. Lawande. 2015. Studies on influence of bagging of fruits at marble stage on quality of mango cv. Alphonso. Journal of Plant Studies, 4 (2):12-20.

Hegazi, A.; N.R. Samra; E.E.T. El-Baz; B.M. Khalil and M.S. Gawish. 2014. Improving fruit quality of Manfalouty and Wonderful pomegranate by using bagging and some spray $\mathbf{J}$ treatments with gibberellic acid, calcium chloride and kaolin. J. Plant Production, Mansoura Univ, 5(5):779 792.

Hussein, A.A.; A.G. Abd El-Rahman and R.B. Ahmed. 1994. Effectiveness of fruit bagging on yield and fruit quality of pomegranate (Punicagranatum, L.) Annals of Agricultural Science, Moshtohor. 32(2):949 - 957.

Islam, M.T., Rahman, M.S., Shamsuzzoha, M., Chowdhury, A.K.M.M.B., Alom, R.2017a. Influence of pre-harvest bagging on fruit quality of Mango (Mangiferaindica L.) cv. Mishribhog. International Journal of Biosciences, 11(3): 59-68.

Islam, M.T., Shamsuzzoha, M., Rahman, M.S., Haque, M.M. and Alom, R.2017b. Influence of pre-harvest bagging on fruit quality of mango (Mangiferaindica L.) cv.Mollika. J. Bioscience and Agriculture Research, 15(1):1246-1254.

Jakhar, M. S. and Pathak S. 2016. Effect of preharvest nutrients application and bagging on quality and shelf life of mango cv. Amrapali.J.Agr. Sci. Tech, Vol. 18: 717729.

Karar. H, Ahmad. M, Ullah. H, Wajid. M, Zubair. M and Raza. H.2019. Effectiveness of Fruit Bagging for the Control of InsectPests Complex and its Impact on Quality of Mango Fruits.Journal of Horticultural Science and Technology, 2(2): 45-48.

Malshe, K.V. and Parulekar, Y. R. 2017.Effect of 
stage of preharvest bagging with skirting bags on fruit quality of Alphonso mango.Internat. J. Proc. \& Post Harvest Technol, 8 (2) : 95-98.

Mingire, S.S., Haldankar, P.M., Parulakar, Y.R., Kadam, D.S., Haldavanekar, P.C., Narangalkar, A.L., Dalvi, V.V. and Kahdekar R.G. 2017. Studies on influence of preharvest bagging of fruits on quality on quality of mango cv. Ratna. Indian J. Horticulture.74 (2): 178-183.

Muchui M. N., F. M. Mathooko, C. K. Njoroge, E. M. Kahangi, C. A. Onyango and E. M. Kimani. 2010. Effect of perforated blue polyethylene bunch covers on selected postharvest quality parameters of tissue cultured bananas (Musa spp.) cv. Williams in Central Kenya. J. of Stored Products and Postharvest, 1(3): 29 - 41.

Rathoreand Pal. 2016. Pre-harvest fruit bagging improves fruit quality of mango in doon valley. HortFlora Research Spectrum 5(1): 84-85.

Salama, M.I., El Morsi A.A., Omar A.K., and El Basyoni, R.I. 2018. Improving yield and fruit quality of "Wonderful" pomegranates using bagging and potassium treatments under kafr El- Sheikh Conditions. Acta Horticulturae. 1216: 105-114.

Samra, B.N. and A.M. Shalan. 2013. Studies on thinning, bagging and aluminium silicate spraying on yield and quality of Wonderful pomegranate. J.Plant Production, Mansoura Univ. 4(2):219 - 227.

Sarkomi F.H., FaridMoradinezhad and Mehdi Khayat (2019). Pre-harvest bagging influences sunburn, cracking and quality of pomegranate fruits. J. Horticulture and Postharvest Research.2(2):131-142.

Saxena, M. (Ed). 2018. Horticultural Statistics at a Glance 2018. Government of India Ministry of Agriculture and Farmers' Welfare Department of Agriculture, Cooperation \& Farmers' Welfare Horticulture Statistics Division. New Delhi. Page No. 183.

Shankar,V., Veeragavathatham, D. and Kannan, M. 2009. Effect of organic farming practices on postharvest storage life and organoleptic quality of yellow onion (Allium cepa L.).Indian Journal of Agricultural Sciences, 79 (8): 608-614.

Singh, A., Burman, U. Santra, P. and Morwal B.R. 2014. Fruit cracking of pomegranate and its relationship with temperature and plant water status in hot arid region of India. Journal of Agrometeorology 16 (Special Issue-I): 24-29.

Wassel, A.H.M.; A.A. Gobara; H.I,M, Ibrahiem and M.M. Shaaban. 2015. Response of Wonderful pomegranate trees to foliar application of amino acids, vitamins B and silicon. World Rural Observations. 7(3):91 -95 .

Wetzstein, H. Y.; Zibin Zhang; NadavRavid; Wet stein, M.E. 2011. Characterization of Attributes Related to Fruit Size in Pomegranate. HortScience 46(6):908-912.

Yilmaz, C., \& Ozguven, A. I. (2005). Hormone physiology of preharvest fruit cracking in pomegranate (Punica granatum L.). In: X International Symposium on Plant Bioregulators in Fruit Production 727: 545550 .

\section{How to cite this article:}

Gethe, A. S., S. A. Hiray, C. V. Pujari and Patil, R. V. 2021. Effect of Pre-harvest Fruit Bagging on Physical and Physiological Properties of Pomegranate (Punica granatum, L.) cv. Phule Bhagwa Super. Int.J.Curr.Microbiol.App.Sci. 10(02): 227-236. doi: https://doi.org/10.20546/ijcmas.2021.1002.028 